\title{
Keeping Secrets: \\ Leslie E. Keeley, the Gold Cure and the Nineteenth-Century Neuroscience of Addiction
}

'The science of phrenology is dead, but it had about the same relation to brain and mental physiology as astrology did to astronomy, or alchemy to chemistry. It was an error, but an introduction.' Dr. Leslie E Keeley, 'The Relation of Mind and Brain,' 17 September 1896

Word Count: Text 7605; Notes 1868; Total 9473

Conflict of Interest: None

\section{Introduction}

In October, 1997, Alan Leshner, then director of the U.S. National Institute on Drug Abuse (NIDA) made an important announcement. In a special edition of the journal Science, he declared that 'addiction is a disease of the brain, and it matters.' He further explained that this sense of addiction as 'a chronic, relapsing disease of the brain is a totally new concept for much of the general public, for many policymakers, and, sadly, for many health care professionals. ${ }^{1}$ The director may have been right about the concept's novelty for its 1997 audience, but as he implied, some readers might have known that the NIDA model was not a new hypothesis. Since the nineteenth century, a broad range of medical researchers have speculated that addiction might be a

In addition to the journal's anonymous readers, I would like to thank Virginia Berridge, David T. Courtwright, Joseph M. Gabriel, Derek Heim and Paolo Paladino for their encouraging words, challenging disagreements and their ever-stimulating scholarship. I presented early versions of this paper to the Alcohol and Drugs History Society, the Society for the Study of Addiction and the Royal College of Physicians and Surgeons, Glasgow.

\footnotetext{
${ }^{1}$ Alan Leshner, 'Addiction is a Brain Disease, and It Matters,' Science vol. 278 (3
} October 1997), 46. 
'brain disease,' or at least a neurological disorder located in the brain. This article examines the career of one of them: Dr. Leslie E. Keeley, the nineteenth century's most famous addiction cure doctor. Keeley distributed his 'Gold Cure' for alcohol, tobacco and drug habits through an international network of franchised, private clinics across North America, England, Continental Europe and Australia beginning in the 1880s. In an unpublished manuscript from 1894, Keeley explained that 'the physiological action of opium is to diminish the natural forces of the nervous system. It does more than this if continued too long, it produces an isomeric change in the structure of the nerve and its action which is expressed by the word morphism.'2 Thinking about past formulations like this one helps us to think about present articulations of addiction. Contrast Keeley's statement with Leshner's 1997 description: 'Not only does acute drug use modify brain function in critical ways, but prolonged drug use causes pervasive changes in brain function that persist long after the individual stops taking the drug. ${ }^{3}$ Both writers contrast shorter with longer periods of drug use and blame a fundamental modification of brain function and neurological structure on the latter. Leshner found that 'significant effects of chronic use have been identified for many drugs at all levels: molecular, cellular, structural, and functional,' ${ }^{4}$ but again, if we jump back in time to Keeley, we find addiction described as a 'pathology,' grounded in an 'isomeric change in the nervous system at large, produced by opium ...

\footnotetext{
${ }^{2}$ Leslie E. Keeley, M.D., 'Pathology of the Opium Disease,' Unpublished Manuscript (1 May 1894). Papers of the Leslie E. Keeley Company, MS box 22, Lincoln Presidential Library, Springfield III., 3.

${ }^{3}$ Leshner, 46.

${ }^{4}$ Ibid.
} 
Every fibre of [a habitual user's] nervous system has undergone the isomeric change of opium.'5

Though it would be absurd to claim or expect their ideas to be identical, their general symmetry is clear. Both describe addiction as a disease that effects the brain's executive function caused by a physiological transformation consequent upon drug use. This raises important historical questions. In the first place, why has Keeley been forgotten? This article's primary goal is to contribute to the efforts of historians who have tried to make Keeley's story more widely known. ${ }^{6}$ Above, I described Keeley as the late nineteenth century's most famous addiction specialist. While tens and even hundreds of thousands of Keeley's contemporaries would have agreed with my description, a much smaller but more powerful cohort would have disagreed profoundly. In fact, the elite medical professionals represented by the American Medical Association (AMA) and the British Medical Association (BMA) described Keeley not as an expert, but rather as the very epitome of quackery and they dismissed both him and his cure. Their attack was so

\footnotetext{
${ }^{5}$ Keeley, 'Pathology...,' 4.

${ }^{6}$ While there is no complete study of life and career of Leslie E. Keeley, several historians have commented on the phenomenon. See George Barclay, 'The Keeley League,' Journal of the Illinois State Historical Society, (Winter, 1964), 341-365; Timothy A. Hickman, 'The Secret Leprosy of Modern Days': Narcotic Addiction and Cultural Crisis in the United States, 1870-1920 (Amherst: University of Massachusetts Press, 2007); H. Wayne Morgan, Drugs in America, A Social History 1800-1980 (Syracuse: Syracuse Univ. Press, 1974); David F. Musto M.D., The American Disease: Origins of Narcotic Control, third edition (New York: Oxford University Press, 1999); Sarah W. Tracy, Alcoholism in America: From Reconstruction to Prohibition (Baltimore: The Johns Hopkins University Press, 2005); Cheryl Krasnick Warsh, 'Adventures in Maritime Quackery, The Leslie E. Keeley Gold Cure Institute of Fredericton, N. B.,' Acadiensis, vol. 27, no. 2 (Spring, 1988), 109130; The most thorough treatment of Keeley's therapeutic practice is William L. White, Slaying the Dragon: The History of Addiction Treatment and Recovery in America (Bloomington, Ill.: Chestnut Health Systems, 1998).
} 
thorough that only a handful of historians and antique bottle collectors still remember the medical empire that was the Keeley Gold Cure. But Keeley's story is worth remembering. Despite the testimony of tens of thousands of cured patients, elite professional physicians dismissed Keeley as a quack. They did not, however, reject his ideas because they were bad science. Keeley's sins were professional: He was rejected because his practice did not meet the norms of the American medical establishment as it grew in power during the late-nineteenth century.

Secondly, my exploration of Keeley's career is meant to add critical perspective to other descriptions of addiction, particularly what historian David Courtwright has called the NIDA paradigm. ${ }^{7}$ Keeley's neuroscience was rejected and forgotten, but NIDA's brain disease model has become the dominant medical explanation of addiction today. This is at least partly because NIDA's vast funding encourages researchers to follow its agenda, but NIDA also backs its claims with evidence that was not available to Keeley. ${ }^{8}$ Modern neuroimaging_brain scan technology—supplies the evidence that NIDA uses to back its statements, but the information provided by the scans is not self-evident and is deeply controversial, even within its own field. ${ }^{9}$ Recent work in Science and Technology Studies further argues

\footnotetext{
${ }^{7}$ David T. Courtwright coined the phrase in 'The NIDA Brain Disease Paradigm: History, Resistance and Spinoffs,' BioSocieties 5 (2010), 137-147.

8 The most commonly cited claim is that 85 percent of the world's funding comes from NIDA, but this figure seems to have slipped out of use. See NIDA News Release for Wednesday, March 1, 2000, at http://archives.drugabuse.gov/newsroom/00/NR3-1.html, accessed 9 December 2015.

${ }_{9}$ Timothy A. Hickman, 'Target America: Visual Culture, Neuroimaging and the "Hijacked Brain" Theory of Addiction,' Past and Present 222 suppl. 9 (April 2014), 207-226. Edward Vul, Christine Harris, Piotr Winkielman, Harold Pashler, 'Puzzlingly High Correlations in fMRI Studies of Emotion, Personality, and Social Cognition,' in Perspectives on Psychological Science 4; no. 3 (2009), 274-290. See also the responses to Vul's findings alongside his original article: http://www.psychologicalscience.org/journals/pps/4 3.cfm; Dan Harvey,
} 
that neuroimaging does not in itself offer sufficient explanation for the NIDA model's acceptance. ${ }^{10}$ This article argues that historical context, in one case professional and in the other political, was crucial—perhaps even decisive-in constructing the viability of each of these examples of the brain disease hypothesis.

\section{Leslie E. Keeley's Nineteenth-Century Brain Science}

Though nearly forgotten today, Keeley's prominence was unrivalled in the 1890s. Between 1892 and 1900 the Keeley Company generated income of more than 2.7 million dollars-which translates to nearly 80 million dollars in twenty-first century currency-and over 500,000 alcoholics and addicts took the Keeley cure between 1880 and $1920 .{ }^{11}$ His success was so great that 'Keeley's name became almost a household word' according to historian $\mathrm{H}$. Wayne Morgan, who writes that 'the billboards and wall sized signs proclaiming the presence of a Keeley Institute were almost obligatory for a city to be up-to-date from the 1890's to the first world war.' 12

Dr. Thomas Davison Crothers was one of Keeley's competitors and was among his harshest critics. ${ }^{13}$ He described Keeley's prominence in the

\footnotetext{
'Imaging Addiction-PET and fMRI are Tools for Better Understanding Drugs' Effect on the Brain,' in Radiology Today 10; no. 10. (2009) p. 16.

10 Science and Technology Studies (STS) is a relatively new field whose goal is to produce research and teaching that enables critical thought by understanding science and technology as social productions. For a helpful description of the field, see Harvard University's STS homepage, http://sts.hks.harvard.edu/about/whatissts.html.

${ }^{11}$ White, 52. My figure of 80 million is based on the Historic Standard of Living. See: Measuring Worth.Com: http://www.measuringworth.com/uscompare/relativevalue.php accessed 31 July 2015.

12 H. Wayne Morgan, Yesterday's Addicts: American Society and Drug Abuse 1865-1920 (Norman: Univ. of Oklahoma Press, 1974), 75.

${ }^{13}$ Crothers was the leading figure in the American Society for the Study and Cure of Inebriety. He became the society's secretary in 1876 and edited its journal for nearly 40 years. He was a close associate of Dr. Norman $\mathrm{H}$. Kerr, who headed the equivalent British organisation, which is today called the Society for the Study of Addiction. Like Kerr in the UK, Crothers
} 
pages of Popular Science Monthly for October 1892: 'within two years one of these empiric specific cures has led all the others in boldness and prominence. Starting from an obscure Western village, it has spread out into many branches, all organized and conducted on one general plan and federated together. Physicians have been enlisted to conduct each branch, companies have been organized, houses hired, and elaborate arrangements made for the work.' 14 The Keeley Company managed its 'federation' from its home clinic in tiny Dwight, Illinois, which lies about eighty miles south of Chicago. Directing a far-flung enterprise from a remote rural location was feasible because Dwight had a station on the Alton and Illinois Railroad, which also meant that patients could travel to the clinic with relative ease. The journey required patients to leave their home environments and local routines, which probably aided their recovery. The Keeley Company made the most of its transportation links and enhanced them with the century's rapidly improving communication technology, making it possible to expand around the globe in the 1890s: from Chicago to London, across continental Europe, south to Sydney, and finally back to Los Angeles. The company sold franchises for Mexico, South Africa and New Zealand, though these were less successful. Keeley himself was an avid traveller and he visited much of the world in his lifetime. By 1895 the Keeley Company could, with justification,

\footnotetext{
was perhaps the leading mainstream medical advocate of the idea that habitual alcohol and drug use was a curable disease. Crothers ran his own recovery hospital in Hartford, Connecticut and championed the role of professional medicine in the cure of addiction. For more on Crothers' antagonism to Keeley, see Timothy A. Hickman, The Secret Leprosy of Modern Days: Narcotic Addiction and Cultural Crisis in the United States, 1870-1920 (Amherst: University of Massachusetts Press, 2007), 48-58.

${ }^{14}$ Crothers quoted in Leslie E. Keeley, M.D., 'The Cure of Inebriety,' Unpublished Manuscript (1892). Papers of the Leslie E. Keeley Company, MS box 23, Lincoln Presidential Library, Springfield III., 2.
} 
claim to 'belt the world' (fig. 1). At the time of Keeley's death in 1900, the company listed 44 operational institutes. By then, clinics throughout Scandinavia and Russia had closed and nearly all of the remainder were in the United States and Canada, but the London franchise remained profitable and did not close until $1928 .^{15}$

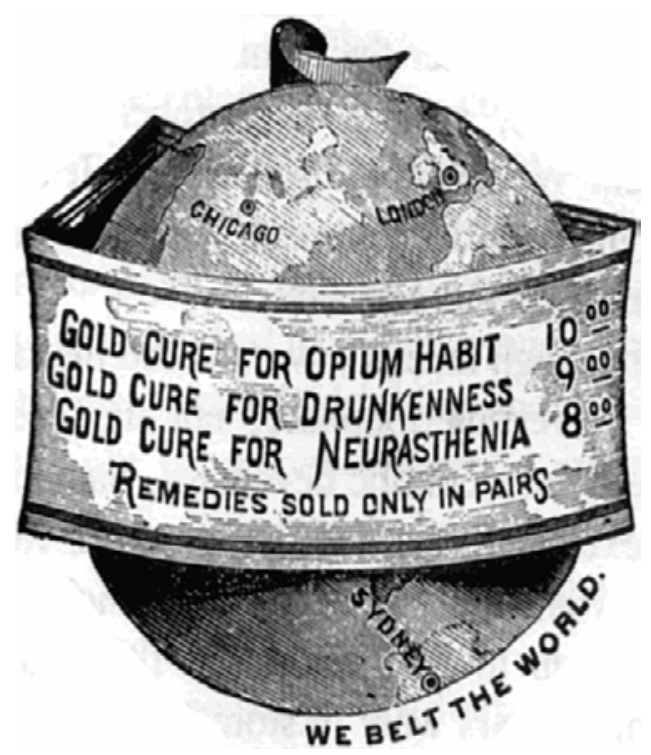

Fig.1 'We Belt the World:' A Keeley Company trademark from the 1890s.

The Dwight cure regime was the model for all of the branches, though the company had a very difficult time ensuring that the others followed the home institute's programme. Nearly all of its physicians were trained in Dwight and many were former patients. ${ }^{16}$ All of the franchises were required to purchase their medication from the home clinic, where its manufacture was a closely guarded secret. Upon arrival in Dwight, patients received an 'attendant' to help with their initial adjustment but, most importantly, the clinic required patients to line up, four times each day, to receive an injection of the Gold Cure tonic (fig. 2), a ritual that historian William L. White describes as

\footnotetext{
15 'List of Defunct and Existing Keeley Institutes, 25 April 1900,' MS. box 4, Papers of the Leslie E. Keeley Company, Lincoln Presidential Library, Springfield III.

${ }^{16}$ White, 53.
} 
'the centerpiece of the Keeley cure.' ${ }^{17}$ The institute required patients, most of whom were there for habitual alcohol use, to remain in Dwight for four weeks. Opium users, however, had to stay for five. Outside of the injection routine, patients were mainly left to their own devices, though the inspirational daily talks, often given by Keeley himself, were an important part of the experience. As many as 30,000 satisfied patients joined one of 370 US chapters of the Keeley League after completing the cure. The League, which produced its own events and publications, played an important part in supporting former patients and in spreading the gospel of the Gold Cure throughout the 1890s. ${ }^{18}$ The popular catchphrase 'I've been to Dwight' signaled one's status as a 'graduate' of the Keeley cure, very much like the slogans that participants used to associate themselves with Alcoholics Anonymous or other twelve-step recovery groups beginning in the mid-twentieth century.

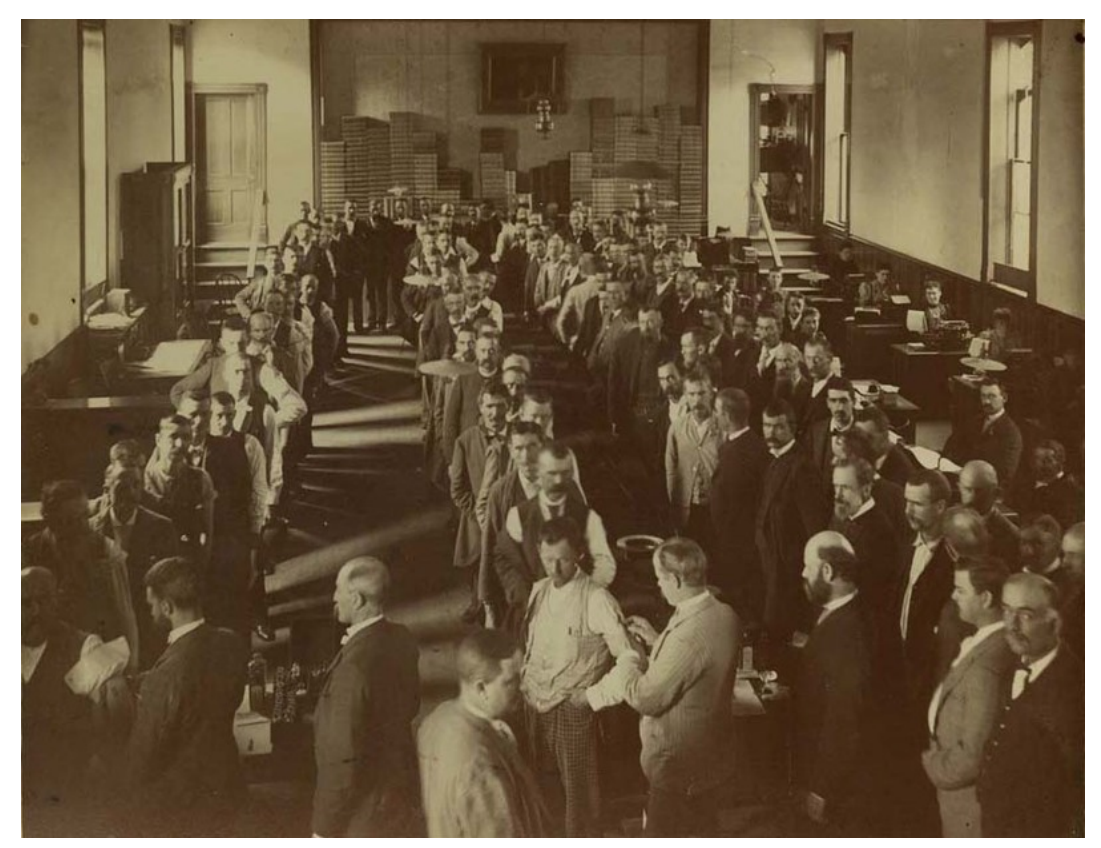

\footnotetext{
17 Ibid., 54.

18 Ibid., 56.
} 
Fig. 2. Patients lining up for Gold Cure injections at the Dwight clinic. Keeley is pictured in the lower right-hand corner, looking up at the camera.

Responding to Crothers' Popular Science article, Keeley agreed that his critic was 'quite correct that the business plan of these institutes... is well systematized, that they are in charge of educated and accomplished physicians, that they are all well patronized, that the methods employed will, do and have cured inebriety in a few weeks. ${ }^{19}$ The exchange with Crothers, from Keeley's perspective, offered hostile corroboration of the Keeley Company's claims about the rigor of its organization. He was adamant that his therapeutic procedure could cure what he described as the brain disease of addiction and repeated the claim throughout his career. As he claimed in 1896, 'I can cure inebriety in any man, under any conditions.' 20

Keeley's statement was far from unique in the 1890s. A host of physicians and medical opportunists claimed that habitual alcohol and drug use was a disease that could be cured, usually by them and for a fee. ${ }^{21}$ Keeley differed from many of his contemporaries, however, by arguing that habitual use was not hereditary. In 1896, he wrote that 'the true pathology of this disease is a craving for the drug which caused the disease, and poisoning by the drug. The disease as such, is not hereditary.' ${ }^{22}$ In his view, 'the heredity of inebriety reaches no further back in any practical sense than the

\footnotetext{
${ }^{19}$ Keeley, 'The Cure of Inebriety,' 3.

20 Leslie E. Keeley, M.D., 'To the Editor...' Unpublished Manuscript (3 June 1895). Papers of the Leslie E. Keeley Company, Box 24, Lincoln Presidential Library, Springfield III., 2.

${ }^{21}$ Musto, 69-90.

22 Leslie E. Keeley, M.D., 'The Disease of Inebriety,' Unpublished Manuscript (2 October 1896). Papers of the Leslie E. Keeley Company, MS Box 22, Lincoln Presidential Library, Springfield III.,1.
} 
cradle and the nursery where children are fed opiates and alcohol for sickness, and even for crying. ${ }^{23}$ Keeley believed that there was no craving, no inebriety, no addiction, which could exist independently of actual drug use, and he believed that the craving came about because the drug poisoned its users. The addictive potential of any substance was thus something that Keeley described as its toxicity; as its ability to poison. He called his theory the non-heredity of inebriety and understood it to be his chief diagnostic contribution to the field, but what is more interesting is the kind of poisoning that Keeley thought he had discovered. ${ }^{24}$ What was poisoned, and what was the consequence?

As we have already seen, Keeley believed that the nervous system was transformed by drug use. Again, in 1896, Keeley wrote that the 'poisoning of nerve tissue comes under another law which is that the poison acts the most where the resistance is least. Alcohol, opium, hasheesh, chloral, ether, etc. follow this rule. In civilized people the higher moral faculties are built up last in brain and mental development. The representative brain tissue is therefore more unstable, and less resistant. ${ }^{25}$ As he put it in an undated manuscript from the mid-1890s, 'the same general law holds good in the pathology of all inebriety. All poisons first put their individual stamp upon the brain and nerve tissues. ${ }^{26}$ Keeley further explained that this brain 'stamping' came about through a sort of neural bonding. He

\footnotetext{
${ }^{23}$ Ibid.

${ }^{24}$ Keeley's most significant scientific publication was his book, The Non-Heredity of Inebriety (Chicago: Scott, Foresman and Co., 1896).

${ }^{25}$ Keeley, 'The Disease of Inebriety,' 6.

${ }^{26}$ Leslie E. Keeley, M.D. 'Dr. L. E. Keeley's Treatment of Inebriety,' Unpublished Manuscript (ND). Papers of the Leslie E. Keeley Company, Box 23, Lincoln Presidential Library, Springfield III., 7.
} 
claimed that, in the act of poisoning, 'the structure of the nerve is changed, every molecule is in company with a molecule of opium, which changes the action of the nerve. ${ }^{27}$ It would be another 75 years until Candace Pert and Solomon Snyder published findings that confirmed the existence of neural opioid receptors in the brain, which is perhaps the corner-stone of the NIDA paradigm. Keeley's speculation differed from later formulations like Pert and Snyder's in its particulars, but his claim that 'it is not unreasonable to suppose that the molecules of opium may hold a relation as close to those of the nerve in this pathology as are the molecules of hydrogen and oxygen in water,' is nonetheless startling from someone so strongly dismissed as a quack. ${ }^{28}$

While Keeley's speculation about the existence of neural opioid bonding is noteworthy, it is drawn from a body of writing that often illustrated his awareness of the state of nineteenth-century neurology. He declared that 'the old pseudo-science of phrenology has developed into a true demonstrated science of brain localization. The brain centres regulating the bodily functions are now accurately located. ${ }^{29}$ This reference to the further development of Paul Broca's 1861 findings on the brain's language centres indicates Keeley's engagement with the mainstream of nineteenth-century neuroscience. ${ }^{30}$ He also noted the problems of brain plasticity, which remains

\footnotetext{
${ }^{27}$ Keeley, 'Pathology...,'13.

${ }^{28} \mathrm{Ibid}$., 4. On the mid-twentieth century emergence of receptor theory, see Scott Vrecko, 'Birth of a Brain Disease: Science, the State and Addiction Neuropolitics,' in History of the Human Sciences vol. 23; no. 4, (2010), 52-67.

${ }^{29}$ Keeley, 'Relation of Mind and Brain,' 1.

${ }^{30}$ On the history of nineteenth-century neuroscience, see Edwin Clarke and L.S. Jacyna, Nineteenth-century Origins of Neuroscientific Concepts (Berkeley: Univ. of California Press, 1992); Stanley Finger, Origins of Neuroscience : A History of Explorations into Brain Function, (Oxford: Oxford Univeristy Press: 1994); Roger Smith, Inhibition: History and Meaning in the Sciences of Mind and Brain (Berkeley: Univ. of California Press, 1992); On localization, see Robert M. Young, Mind, Brain and Adaptation in the Nineteenth Century: Cerebral Localization and its Biological Context from Gall to Ferrier (Oxford: Oxford University Press,
} 
a strong challenge for those who argue that brain function can be unequivocally linked to discrete cerebral regions. ${ }^{31}$ In 1896, Keeley explained the difficulty, writing that 'when the left brain becomes diseased the right side gradually takes up the duties and functions. Thus the loss of speech, paralysis, various incoordinations, and no doubt mental diseases are repaired or cured by this action of the brain.' 32

Most importantly, however, Keeley's chief concern was the therapeutic value of his theory, that is, the possibility of cure. The Keeley Company was in the business of selling its 'Gold Cure,' whose formula was very much a secret. The tonic was allegedly based on the 'bi-chloride of gold' as its active ingredient. Gold was an old homeopathic remedy and a powerful rhetorical tool in late-nineteenth century American political culture. ${ }^{33}$ The company made the most of gold's figurative value in its advertising, but Keeley also understood his cure in terms of its direct application to addiction's status as a brain disease: 'Gold acts primarily upon the nerve tissue that is most unstable or that is highest in its complex development and function. This nerve tissue is the brain.' ${ }^{34}$ He argued that gold 'will cure a diseased nerve as well as develop those which are too small to otherwise be discovered,' and explained that 'it will be seen from these facts that the effect of gold upon nerve tissue restoring it to a natural condition is perfectly marvelous.' 35 Put another way, he claimed that 'the Gold Cure destroys the education imposed on the brain

\footnotetext{
1991); Susan Leigh Star, Regions of the Mind: Brain Research and the Quest for Scientific Certainty (Palo Alto: Stanford University Press, 1989).

${ }^{31}$ Hickman, 'Target America,' 211.

32 Keeley, 'Relation of Mind and Brain,' 4.

33 Timothy A. Hickman, "'Mania Americana": Narcotic Addiction and Modernity in the United States, 1870-1920,' Journal of American History 90 no. 4 (March 2004): 1269-1294.

${ }^{34}$ Keeley, 'Pathology,'13

35 Ibid., 11-12
} 
by drinking. It breaks up the whole list of symptoms—-the crave for liquor, the debauch, the period of sobriety, the remorse. It regenerates the diseased tissues. ${ }^{36}$ For Keeley, gold was an effective cure because it worked directly upon the brain.

\section{Keeley and his Critics}

Those who dismissed Keeley paid little attention to his pathology of addiction—his sins lay elsewhere. Indeed, they had to, because the idea that addiction was a brain disease was far from uncommon in late-nineteenth century medical circles. In 1928 Charles Terry and Mildred Pellens published The Opium Problem, a massive survey of mainstream medical thought on narcotic addiction before 1920. The book contains hundreds of references to the effect of opiates on the brain and nervous system and offers vast evidence of the widespread conception of habitual opiate use as a brain disease that impaired the user's will power. ${ }^{37}$ Terry and Pellens' book concentrates on opiate use, but similar theories were common in studies of alcohol as well. A survey of that enormous body of material is beyond the scope of this essay, but it shows that Keeley's conception of addiction as a brain disease was not particularly novel for its time. It is by no means sufficient to explain his rejection by the medical mainstream. For that, we must turn away from the medical content of his ideas and look instead at his professional practice. It was the secrecy of Keely's Gold Cure and his self-

\footnotetext{
${ }^{36}$ Ibid., 8

${ }^{37}$ Charles E. Terry and Mildred Pellens, The Opium Problem (Montclaire, New Jersey: Patterson Smith, 1928).
} 
reported success rates that led to his marginalization and dismissal as a quack.

After Keeley's death, a writer at the British Medical Journal (BMJ) explained that

Dr. Keeley was for many years an orthodox practitioner of medicine. Then he left the broad highway of legitimate practice, and took a short cut to fortune by a secret path. He was a man of keen intelligence, and, it might have been thought, had sufficient scientific knowledge to recognise humbug when it came before him. Yet here we find him fallen, among quacks, and on his deathbed accepting the ministrations of the most foolish and futile of all pretenders to the power of healing.... The manner of Dr. Keeley's death was a sad illustration of the Nemesis of quackery. ${ }^{38}$

Keeley's wife was a prominent Christian Scientist, and in what must have been a moment of fear and desperation she summoned some of her associates as her 63-year old husband lay dying after a heart attack at the couple's winter home in Los Angeles. ${ }^{39}$ The BMJ made the most of this, even though Keeley had publicly denied any influence or belief in the era's popular 'mind cures.' 40 He had also spent much of the 1890 s contesting attacks like those in the BMJ obituary. As he put it, 'the ethics of the medical profession is to denounce... anything in medicine which is not strictly ethical,' by which he meant that the profession rejected whatever failed to meet what he described as its idiosyncratic, self-serving and outmoded code of ethics. As we will see, Keeley was not alone in his critique of medical codes of ethics, but for now we need to note that his point of contention was that 'the Gold Cure for inebriety,

\footnotetext{
${ }^{38}$ Dr. West Hughes, 'The Nemesis of Quackery,' The British Medical Journal vol. 1; no. 2054 (14 April 1900); 921.

39 Obituary, Chicago Times Herald, (22 February 1900). 'In Memoriam, ' Papers of the Leslie E. Keeley Company, Lincoln Presidential Library, BV 360.

${ }^{40}$ On the late-nineteenth century popularity of 'mind cures,' see Anne Harrington, The Cure Within: A History of Mind-Body Medicine (W.W. Norton and Co., 2009); T. J. Jackson Lears, No Place of Grace: Antimodernism and the Transformation of American Culture, (Pantheon, 1983).
} 
though it cures thousands of this disease, is not considered quite "ethical" because the special formula is not made public.' ${ }^{41}$

Though Keeley made no mention of the AMA in his critique, the organisation's code of ethics offers the definitive example of what he was up against. Adopted at the group's 1847 founding, the code held that it was 'derogatory to professional character... for a physician to hold a patent for any surgical instrument, or medicine; or to dispense a secret nostrum, whether it be the composition or exclusive property of himself, or of others." 42 Mainstream physicians and pharmacists believed that medical knowledge should be shared freely and openly, which is why they placed therapeutic secrecy among the most obvious signs of quackery. Though the midnineteenth century AMA did not have the power or authority that it would achieve by the early twentieth century, its code of ethics was widely influential—particularly as a model for many state medical associations—and, as historian Joseph M. Gabriel has shown, the issue of secret and patent medicines was important enough to find a place in the very first version of the code. ${ }^{43}$

Today, most people assume that secret cures lie outside the field of legitimate medicine, but this is not the case. Secret ingredients are permissible in patented medications, presuming that they are not medically

\footnotetext{
${ }^{41}$ Leslie E. Keeley, M.D., "Does Bichloride of Gold Cure Inebriety?" Unpublished Manuscript (1892). Papers of the Leslie E. Keeley Company, MS box 24, Lincoln Presidential Library, Springfield III., 5.

42 Joseph M. Gabriel, 'A Thing Patented is a Thing Divulged: Francis E. Steward, George S. Davis and the Legitimation of Intellectual Property Rights in Pharmaceutical Manufacturing, 1879-1911,' Journal of the History of Medicine and Allied Sciences, vol. 64; no. 2, (April 2009), 143. For the full development of the argument, see Joseph M. Gabriel, Medical Monopoly: Intellectual Property Rights and the Origins of the Modern Pharmaceutical Industry (Chicago: University of Chicago Press, 2014).

43 Gabriel, 'A Thing Patented,' 143. Gabriel, Medical Monopoly, 58-9.
} 
active ingredients. These so-called excipients might create colours, tastes, consistencies and textures. They add to the distinctiveness of pharmaceutical products and help build brand identity, but they often remain undisclosed by the manufacturer. In the nineteenth century, however, many producers of ready-made, easy-to-use remedies, including Leslie E. Keeley, kept their entire formulas secret in order to protect themselves from competition and to guarantee a reward for their efforts, despite the AMA's injunction against it. ${ }^{44}$ Further, even the BMJ acknowledged Keeley's status as a licensed physician of over thirty years standing by the time accusations of quackery against him reached their peak in the 1890s. Keeley was the product of an earlier era. He was born in 1834 and he received his degree from Chicago's Rush Medical College in 1864. He immediately enlisted as a Civil War surgeon and became interested in the problem of habitual drunkenness after observing the soldiers' heavy drinking. At the War's conclusion, he re-located to rural Dwight as a physician for the Alton and Illinois Railroad. His practice required him to ride a 400 -mile rural circuit on horseback. By the 1880 s he had spent most of his life experimenting with cures for habitual alcohol and drug use in a challenging rural setting, long before professional biomedicine consolidated its dominance of American medical practice. In this context, Keeley's advocacy of a secret cure was not peculiar. It was a common element of an older system of medical practice that sociologist Paul Starr describes as a relatively open and competitive precursor to the more centralised, professional structure that would finally assume power by the First World War. ${ }^{45}$ We should not be

\footnotetext{
44 Ibid, 141.

${ }^{45}$ Paul Starr, The Social Transformation of American Medicine: The Rise of a Sovereign Profession and the Making of a Vast Industry (New York: Basic Books, 1982), 60-78.
} 
too surprised that Keeley's model of medical practice was individualistic and entrepreneurial rather than open and consortial, nor that he fell afoul of those who championed the latter. ${ }^{46}$

Gabriel makes clear that debates about the status of intellectual property were essential to American medicine's late-nineteenth century transformation. Keeley maintained secrecy in order to protect what he felt was his intellectual property. He might have patented the bi-chloride of gold, but, as we've seen, the AMA code branded that unethical as well. Many, perhaps most, medical professionals believed that patenting was only slightly better than secrecy. Furthermore, patents expired and they required the disclosure of the formula, which meant that others might approximate the cure or steal it outright, leaving time-consuming, expensive and uncertain litigation as the only recourse. ${ }^{47}$ If a formula was simple, then its escape into general circulation would be impossible to contain. Keeley insisted that the bi-chloride of gold was effective as the central part of a broader treatment programme administered by specialists: Dwight-trained physicians working at franchised Keeley clinics. He argued that the expertise of his staff underwrote the Gold Cure's effectiveness. ${ }^{48}$ This strategy was not unique to Keeley. ${ }^{49}$ He insisted that making his formula public_-and thereby losing control of it-could have

\footnotetext{
${ }^{46}$ On medical professionalization, see John Haller, American Medicine in Transition, 1840-1910 (Urbana, University of Illinois Press, 1981); John Harley Warner, The Therapeutic Perspective: Medical Practice, Knowledge and Identity in America, 1820-1885 (Princeton, N.J., Princeton University Press, 1997); Starr, Social Transformation.

47 Gabriel, Medical Monopoly, 43-57, 80-81.

48 Leslie E. Keeley, 'Editor, Tribune,' Unpublished Manuscript (1 May 1894). Papers of the Leslie E. Keeley Company, MS Box 23, Lincoln Presidential Library, Springfield III.

${ }^{49}$ Henry J. Bigleow, for instance, had made a similar defense of William T. G. Morton's controversial 1846 patent on ether, arguing that limiting its use to specially trained and licensed physicians might help mitigate the anesthesia's inherent dangers. See Gabriel, Medical Monopoly, 62-3.
} 
no medical benefit because only properly trained and supervised physicians could use the medication effectively. He argued that disclosure of the formula would rob him of his life's work and deprive the public of a successful cure for a devastating medical condition.

Keeley was articulate, knowledgeable and confident. He did not hide or deny his use of secrecy and was not about to back down to those he saw as professional upstarts. He explained that 'the world is clamoring for the secret of my cure... They demand my property in the name of "humanity,' and he argued that his only 'crime consists in being paid for honest and successful work. It is not a detriment to the morality of this work if the magnitude is great. ${ }^{150}$ This appeal to the rights of private property and free trade—central tenets of American liberalism—-helps us to situate Keeley's thought within the contested, transitional culture of late-nineteenth century America. As we have seen, Keeley was a Civil War veteran from the northern state of Illinois and his strong support for the Republican Party of Illinois' favourite son, Abraham Lincoln, is evident in his abundant correspondence. By 1896 Keeley disliked Populism, the Democratic presidential candidate William Jennings Bryan and farmers in general, at least partly because he believed they were Democrats. Keeley backed Republican William McKinley for president, and the proprietor of the Gold Cure's support for the candidate and party of the monetary Gold Standard should surprise no one. As he wrote to one long-term correspondent, 'I am not a silver inflationist, nor will I ever be. Gold is the

50 Keeley, 'Editor, Tribune,' 9. 
proper standard and the only standard that this government can "win out" upon. ${ }^{51}$

Keeley's defense of his medical practice drew much of its sense from its broader, nineteenth-century social and political context. His words exemplify what Eric Foner has described as the transformation of the antebellum Republican Party's 'free labour ideology' into the late-nineteenth century creed of American business. ${ }^{52}$ In 1894 , Keeley defended his right to what Lincoln earlier called 'the bread that his own hand earned,' but updated that entitlement with a turn of phrase that was particularly resonant only eight years after Chicago's 1886 Haymarket Square Riots, where seven people were killed and scores more wounded in a labour uprising that many blamed on anarchists. ${ }^{53}$ Keeley declared that his professional accusers 'sort of ethics underlies anarchy.' He explained that, 'according to this terrible social theory, no man has any right to property in thought, or knowledge, or money, if an anarchist should want it. It seems to me that laws are made and maintained to protect people in the rights of property—mental property as well as money. ${ }^{54}$ Though Keeley's insistence on a secret remedy was an element of a fading paradigm where no single group of physicians had the power to quash a particular strand of medical thought or therapeutic practice, his position was not simply a relic from the past. Keeley brought it up to date,

\footnotetext{
${ }^{51}$ Keeley to Wm. H. Bradbury, Esq., 17 July, 1896. Papers of the Leslie E. Keeley Company, Lincoln Presidential Library, Springfield, Illinois, BV1, 380.

${ }^{52}$ Eric Foner, $A$ Short History of Reconstruction (Harper Perennial, 1990), 12-13.

${ }^{53}$ Lincoln made this paradigmatic statement of the rights of free labour in his first senatorial debate with Democrat Steven Douglass, Ottowa, Illinois 21 August,1858. See Robert C. Bray, Reading With Lincoln (Southern Illinois University Press, 2010); On the Haymarket links with anarchists, see Paul Avrich, The Haymarket Tragedy (Princeton University Press, 1984).

${ }^{54}$ Leslie E. Keeley, 'Editor, Tribune,' 7.
} 
mounting his defense in timely metaphors and tropes drawn from its latenineteenth century, American social context.

Keeley's language was drawn from a fiercely contested political dispute and was intended to appeal to a broad audience, but it was also embedded within a more specifically medical quarrel. As historian John Harley Warner argues, this period is notable for 'the emergence among American physicians of incommensurable belief systems, divergent notions of how moral values and ethical behavior in the profession should be defined and upheld. 55 Keeley's rhetoric of liberalism was in many ways consonant with arguments made by a group of prominent, mainstream physicians, whose critique of the AMA code was likewise drawn from middle-class support for free trade and opposition to labour unions. As Warner has shown, these physicians argued that they, as members of a liberal profession guided by science, should not be obstructed by paternalistic codes of practice that were more suited to medieval guilds_-or trade unions — than to modern medicine. ${ }^{56}$ Among the concerns of some was that inadequate protection of intellectual property in a competitive marketplace threatened to deprive scientific innovators of at least part of their motivation. ${ }^{57}$ These physicians, pharmacists and drug manufacturers were not people who wished to defend the old order, but quite the contrary. They wanted to bring medical practice up to date; to bring it into line with the laboratory practice of a rapidly changing scientific world, including its new pharmaceutical discoveries. ${ }^{58}$ In Keeley's words, the medical profession 'will fight the question many years, possibly, but will some day

\footnotetext{
55 Warner, 'The 1880s Rebellion,' 52.

56 Ibid., 61.

57 Gabriel, 'A Thing Patented,' 159, 170. Gabriel, Medical Monopoly, 123, 135, 165.

58 Gabriel, 'A Thing Patented,' 162-3. Gabriel, Medical Monopoly, 86-87.
} 
incorporate into the code of ethics a provision which will give a physician a proprietary right to his inventions relating to surgical instruments and remedies. ${ }^{59}$ He was right, but by the First World War stronger use of patents, not secrecy, would come to be accepted as legitimate protection of intellectual property. ${ }^{60}$ Keeley backed the wrong horse, but his defense of secrecy must be understood within the broad parameters of that complex and contested transformation.

The modernizing element of Keeley's thought was even more clearly on display in his celebration of 'the modern progress of medical science,' and particularly the laboratory as a source of medical knowledge. ${ }^{61}$ Here again his critical attitude toward ethical codes was in step with arguments made by other medical reformers, this time with physicians who championed laboratory experimentation as a guide for therapeutic practice. These reformers thought that the AMA code hindered medical progress because it rejected breakthroughs by laboratory-based scientists in favour of slowly acquired knowledge, derived from the clinical practice of a community of like-minded physicians. ${ }^{62}$ Keeley agreed with the reformers, declaring that 'the pathology of inebriety is not demonstrable by physical examination of any kind. Its nature is only determined by inference or deduction from the established laws of biology. ' ${ }^{63}$ Keeley's support for determining and applying 'established laws' over and above 'physical examination' deviated sharply from primary reliance

\footnotetext{
${ }^{59}$ Keeley, Non-Heredity, 15. On a similar AMA proposal, made and dropped in 1894, see Gabriel, Medical Monopoly, 164-165.

${ }^{60}$ Gabriel, 'A Thing Patented,' 171. Gabriel, Medical Monopoly, 241.

${ }^{61}$ Keeley, Non-Heredity, 20-22.

62 John Harley Warner, 'Ideals of Science and their Discontents in Late Nineteenth-Century American Medicine,' Isis, vol. 82, no. 3 (Sept. 1991), 462. Gabriel, Medical Monopoly, 59, 61. ${ }^{63}$ Keeley, 'Disease of Inebriety,' 9.
} 
on clinical experience and was at strong variance with the AMA code in 1896. For Keeley and like-minded reformers, the biological laws came first. They directed practice, rather than simply explaining it. Warner calls this the 'physiological method' and explicitly contrasts it with the 'empirical method' enshrined in the code. ${ }^{64}$ Keeley was unequivocal about the scope, origin and method of his programme: 'My treatment is based entirely upon special medication, and is the result of my studies and investigations of the physiological effects of gold upon the nervous system.'65 This 1896 declaration places him very much within a cohort of what Warner identifies as 'intellectually active' physicians who, by 1885 , had begun 'to see reductionist knowledge of physiological processes and drug action in the laboratory as the chief starting point for scientific reasoning in the clinic.' ${ }^{66}$ Through laboratory research, physicians might learn about disease function and how drugs altered it, leaving them to match 'the appropriate drug to the deviant physiological process. ${ }^{67}$ Keeley explained that such methods had helped him to match gold with the brain disease of inebriety, but his insistence on secrecy is what mattered most to his critics. Outside of those who staffed the Gold Cure clinics, Keeley found few mainstream medical allies, whatever their stance on the AMA code's attitude to laboratory science.

For all of these reasons, Keeley argued that attacks on his medical ethics were the self-serving statements of a reactionary clique whose mere existence held back medical progress. He felt that 'one of the greatest difficulties in the way of medical development has been the formation of

\footnotetext{
64 Warner, 'Ideals of Science,' 457.

65 Keeley, 'Pathology of the Opium Disease,' 11.

${ }^{66}$ Warner, Therapeutic Perspective, 7.

67 Warner, 'Ideals of Science,' 457-8.
} 
medical creeds,' and that 'the characteristic of these creeds is that no one ventures to let his wanton thought and experiments wander outside these confines.' As illustration, he noted that 'Jenner violated the creeds of his day, as did Pasteur, Koch and Hahnemann.' ${ }^{68}$ He pointed out that 'germ theory was ridiculed for fifteen years, while its defenders were ranked as "quacks."69 He noted, however, that the old creeds formulated from 'dogmatic generalities rather than from laws discovered from the verification of facts relating to the cause of disease,' were on the wane. Keeley rejoiced that 'Dr. Koch's demonstrated discoveries made a science of medicine possible. ${ }^{70}$ Keeley's claim for the value of the modern medical laboratory could not have been stronger: 'As I have indicated, or quoted, medical science is standing on the threshold of a new era-she is gazing bewildered and delighted and triumphant into a new laboratory, wherein is manufactured special cures for all the special diseases to which humanity is heir. ${ }^{71}$

Besides implicitly linking himself with several of the nineteenth century's most significant medical figures, his addition of Samuel Hahnemann, the founder of Homeopathy, to the list above was another important and controversial declaration. Among the most divisive elements of the AMA code was its non-consultation clause, which held that its physicians should not consult with members of other 'sects. ${ }^{72}$ The New York state medical association actually split in 1884 over whether or not to remove the clause

\footnotetext{
${ }^{68}$ Keeley, Non-Heredity, 13.

69 Ibid., 15

70 Ibid., 33. Robert Koch followed Louis Pasteur's pioneering work in bacteriology. He developed a laboratory method in the 1870s that he and others used to isolate the bacteria that caused Anthrax, Tuberculosis, Cholera, Typhus, Tetanus and Plague between 1876 and 1900.

${ }^{71}$ Leslie E. Keeley, 'Does the bi-Chloride of Gold Cure Inebriety?' 24.

72 Warner. '1880s Rebellion,' 55.
} 
from its code of ethics. ${ }^{73}$ The clause was aimed primarily at Homeopaths, but those who challenged it believed that science should be the judge of medical propriety, not restrictive codes of practical ethics. Keeley wrote that 'the pretense of "regular medicine" is that all dogmas are rejected; but the meaning is that all new things are rejected. ${ }^{74}$ He felt that Hahnemann's infinitesimal doses had been carried to an unhelpful extreme but argued that they had been an important corrective to the aggressively antagonistic, 'heroic' therapies of the early nineteenth century—from powerful and debilitating emetics to bloodletting. He believed that Hahnemann's approach was a step forward, showing that he was happy to 'consult' with any medical field, so long as its therapy was effective, but to Keeley and many others, the AMA code favoured factionalism over science. ${ }^{75}$ As he wrote, "the "grand old profession" generally ends by adopting everything. It will some day, if its morals improve, adopt all the pathies. ${ }^{176}$ Keeley felt that all of these approaches had contributed to modern medicine and his writing shows the belief that physicians should draw on the full range of medical knowledge based on effectiveness, not on the confirmation of a particular code of practice.

Keeley's reliance on effectiveness as the marker of medical value leads to a final site of controversy-the $95 \%$ success rates claimed for the Gold Cure, particularly in Keeley Company advertising. This claim was the bedrock of Keeley's defense. It underwrote nearly all of his arguments, whether about medical ethics, laboratory science, therapeutics or even

\footnotetext{
73 Ibid., 57.

${ }^{74}$ Keeley, Non-Heredity, 14.

${ }^{75}$ Gabriel, Medical Monopoly, 134.

${ }^{76}$ Keeley, Non-Heredity, 15.
} 
intellectual property. As he put it: 'I hold myself justified in keeping my own remedy as my own property, and I am justified by the success of the remedy in my own hands. ${ }^{77}$ According to an 1897 Keeley publication, the 95\% success rate had been confirmed in a follow-up study of 1000 recovered morphine users, but critics sometimes claimed to find rates as low as $51 \% .{ }^{78}$ Whatever the actual figure was, it is impossible to deny that many thousands of people believed that they had been cured by the Keeley programme. This is evident in the 30,000 members of the Keeley League noted above and in the popular confessional writing of former patients. Most importantly, it animates every page of the vast number of patient letters that are held in the Keeley Company papers. Typical is one former patient, who wrote to the Dwight clinic in 1940, marking the $49^{\text {th }}$ anniversary of his sobriety: 'I was seventy-three years old my last birthday and I was twenty-four and one month old when I arrived at Dwight to take your treatment.' After noting his long and successful career in the New York State medical service, he proudly stated that he had 'done everything in the sporting line during that time.' Most significantly, he declared that 'I have never forgotten and I think of you every day of my life and the good that your cure has done for me and of how happy my people all were before they passed away. ${ }^{79}$ If the New Social History of the past 40 years has taught historians anything at all, it is that we disregard passionate self-assessments like this at our peril. We risk simply repeating

\footnotetext{
77 Keeley, 'Editor Tribune,' 13

78 White, 57, 59.

79 Patient name withheld. Letter to James H. Oughton, April 19, 1940. Papers of the Leslie

E. Keeley Company, Lincoln Presidential Library, Springfield, Illinois, Box 17.
} 
the gesture of the elite physicians who dismissed such testimony as the misguided utterances of a naïve and gullible public. ${ }^{80}$

It is impossible to tell why the cure was effective for satisfied expatients. Keeley died suddenly and never revealed the Gold Cure's formula. His business partners also took their secrets with them to the grave. A variety of competitors and critics analysed the Gold Cure for its contents, but their results varied and were inconclusive at best. ${ }^{81}$ Looking backwards, historians might argue that the remedy was a placebo, but we can never know. After a great deal of research in Keeley's private papers I have yet to find even the slightest hint that he was ever less than $100 \%$ confident in the effectiveness of his cure. As he wrote to a correspondent only three months before his death, 'let me say that the talk you have heard about the bad effects of my remedy is all false. The remedy is only a tonic, but the best tonic on the face of the globe. A barrel full of it fed to a child under proper restrictions would do no more harm than the taking of so much spring water. ${ }^{182}$ Though Keeley never waivered in his belief in the cure, today's reader might find a more convincing explanation in the broader effect of the four-week Keeley programme; in its routine of inspirational talks, good food, and healthy living, supported by an enthusiastic aftercare network of recovered patients. As such, Keeley might be best remembered as an important but forgotten figure in the history of addiction treatment, along with Bill Wilson, Chuck Dederich and others who developed franchised, international programmes based on ritual and longterm community support. From this angle, Keeley's work at Dwight was

\footnotetext{
${ }^{80}$ Gabriel, Medical Monopoly, 29.

${ }^{81}$ White, 59.

82 Keeley to Mrs. Hattie E. Wilson, Oakland CA, 22 Nov. 1899, Papers of the Leslie E. Keeley Company, Lincoln Presidential Library, Springfield, Illinois, BV1, 380.
} 
perhaps a forerunner to the treatment communities that would emerge later in the twentieth century. ${ }^{83}$ Addiction historian and therapist William L. White notes that 'Keeley introduced an approach that carried an aura of scientific truth and all the emotional support and intensity of a revival meeting,' and believes that similar approaches could be effective today. ${ }^{84}$ Debates about why, whether or how the cure 'really' worked, however, are somewhat beside the point. What matters most is that-for whatever reason-tens of thousands of people believed that the Keeley programme had cured them.

When accused of exaggerating his success rate, Keeley stated simply that when a patient left one of his clinics, he or she no longer craved alcohol or drugs, but added that the physician was not responsible for anything further. When patients completed the Keeley programme, they received a pamphlet that explained they were cured-that they no longer craved alcohol or drugs_-but it also emphasized that their addictions would return if they took alcohol or drugs again. White notes that the pamphlet encouraged them to look after each other, to keep in touch with the Dwight clinic and to maintain the practices they had developed while in therapy, from healthy eating to regular sleep. ${ }^{85}$ In 1895 Keeley wrote that, though he could cure any man that came to him, 'I cannot make his environment for him to live in afterwards. I do not claim either that inebriety can be so effectually cured that a man cannot drink if he wills so to do... If he drinks again, he does it because he becomes reckless, through illness or misfortune, or because for some reason,

\footnotetext{
${ }^{83}$ On the emergence of the treatment communities, see Claire D. Clark, Recovery Revolutions: The Battle over Addiction Treatment in the United States (New York: Columbia University Press, 2017).

${ }^{84}$ White, 62.

${ }^{85}$ White, 55.
} 
he cannot appreciate a condition of sobriety." ${ }^{86}$ As he told his long-time friend and colleague H.A. Kenyon, ‘you can’t inject brains into a man with a hypodermic syringe. ${ }^{87}$ At least to my ear, these arguments do not come across simply as the words of a self-serving quack. Today, in fact, the notion of relapse is taken as a given in theories of addiction ranging from popular twelve-step programs all of the way up to the NIDA paradigm itself, which, as we saw above, defines the condition as a chronic and relapsing brain disease.

\section{Contextualising Addiction(s)}

My reference to NIDA drags us back to the present. We have seen that the idea of addiction, or inebriety, as a brain disease was not a new concept in 1997. Leslie E. Keeley was just one physician who made similar claims over a century beforehand but they have been largely forgotten. His story is important partly because his theory of addiction as a brain disease adds historical perspective to current thinking, partly because of his vast, international popularity in the 1890s and partly because his evocative and powerful prose offers vivid images of late-nineteenth century popular medical culture. All of these are significant, but what matters most for this article is that, despite the testimony of tens of thousands of cured patients, Keeley was dismissed by elite professional medicine as a quack.

I have argued that it was less his theory of addiction that got him into trouble, than it was his failure to conform to a code of professional ethics that he refused to accept. Keeley's critique of medical ethics as an impediment to

\footnotetext{
${ }^{86}$ Keeley, 'To the Editor' 2.

87 Obituary, Dwight Star and Herald, 24 February 1900. 'In Memoriam, ' Papers of the Leslie

E. Keeley Company, Lincoln Presidential Library, BV 360.
} 
therapeutic progress was similar to accusations made by mainstream physicians who also felt that laboratory science offered a better grounding for medical knowledge and practice. He also shared the concerns of those who believed in more effective protection of intellectual property in medicine. When placed in context therefore, we can see Keeley's self-defense in terms broader than mere self-interest-though it was that too. Nor was it simply drawn from an older, more permissive medical paradigm. Keeley defended the antiquated practice of secrecy in the uncompromising language of a medical modernist. That mixture was no easier for his critics to digest at the turn of the twentieth century than it is for historians to pigeonhole at the beginning of the twenty-first, which helps to explain Keeley's descent into obscurity. The erasure of Keeley's story is a consequence of the elite criticism he received in a late-nineteenth century power struggle that helped to shape the medical profession in the United States and beyond, but historians perpetuate that process if they tell only the victors' story and drop figures like Keeley from the record. This article has argued that Keeley's story, unlike his cure, should not be kept secret; that it deserves inclusion in the history of addiction medicine on its own merit. Writing it back into the record, however, raises a number of historiographical and practical issues.

First, the elite rejection of Keeley's popular success casts light upon the decisive role played by the changing contexts wherein medical explanation and therapeutic practice happen, rather than simply focusing our attention on narrowly defined scientific content or even results. Inevitably, insights about the past raise questions about the present. In this case, the substantive symmetries between Keeley's rejected brain science of inebriety 
and NIDA's prevailing brain science of addiction beg us to consider the contextual issues that endorse or disallow any theory of addiction. This article has begun to do so by examining Keeley's career, but scholars in Science and Technology Studies have argued that NIDA's version of addiction is also a model whose truth-value has been generated by its grounding within a broader neuroscientific paradigm. Nancy D. Campbell, Scott Vrecko, Joseph Dumit, Kelly A. Joyce and others have described that broader paradigm as a brain-centric worldview that is itself a historical product, shot through with social and cultural currents that transcend strictly medical or scientific explanation. ${ }^{88}$

Vrecko, for instance, argues that 'the very origins of neuroscience studies of drugs and addiction in the postwar era were closely tied to American social and political concerns about drugs. ${ }^{89}$ This was so particularly because the funding for neuroscientific addiction research became available thanks to the Nixon administration's late-1960s drug policy. As I noted above, Solomon Snyder and Candace Pert made perhaps the key finding in support of the brain disease hypothesis when they proved the existence of longconjectured opioid receptors in the brain in 1973. Yet Snyder explained that

\footnotetext{
${ }^{88}$ Nancy D. Campbell, 'The Metapharmacology of the "Addicted Brain",' History of the Present 1; no. 2 (Fall, 2011), 194-218; Joseph Dumit, Picturing Personality: Brain Scans and Biomedical Identity (Princeton: Princeton University Press, 2004); Scott Vrecko, 'Birth of a Brain Disease: Science, the State and Addiction Neuropolitics,' History of the Human Sciences 23; no. 4 (2010), 52-67; Kelly A. Joyce, Magnetic Appeal: MRI and the Myth of Transparency (Ithaca: Cornell University Press, 2008); Ian Walmsley, 'Coming off drugs: A Critical History of the Withdrawing Body,' Contemporary Drug Problems, 43; no. 4 (2016), 381-396.
}

${ }^{89}$ Vrecko, 55. 
in the 1960s he 'hardly knew heroin from horseradish.' ${ }^{90}$ Vrecko reports that Snyder and his team chose opiates as a field of investigation 'simply because funding had been readily available for researchers whose projects could be aligned with the US government's War on Drugs.' 91 'A few decades later,' Vrecko explains, 'addiction is no longer imagined as a brain disease; it is a brain disease as a matter of facts-though of course these are state-

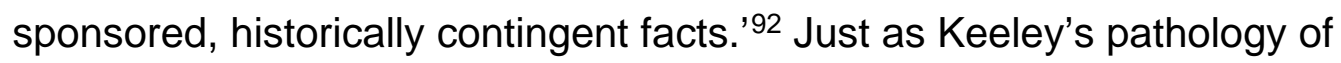
inebriety was rejected because of (professional) context, in Vrecko's analysis, NIDAs brain-disease model has triumphed because of (political and social) context.

This is not to say that context is the only issue. The content of addiction science does indeed matter, and it may be tempting for historians and social scientists to take a position on the validity of the medical findings themselves. Most historians, however, do not have the expertise to determine whether NIDA's claims are medically correct, but, following sociologist Peter Conrad's suggestion, we can 'bracket the question' of whether claims like Keeley's or indeed NIDA's identify 'real' medical problems. Conrad explains that 'what constitutes a real medical problem may be largely in the eyes of the beholder or in the realm of those who have the authority to define a problem as medical. It is the viability of the designation, rather than the validity of the explanation that is grist for the [historical] mill.' 93

\footnotetext{
${ }^{90}$ Solomon Snyder, Brainstorming: the Science and Politics of Opiate Research (Cambridge, Mass.: Harvard University Press, 1989), 6. Quoted in Vrecko, 59.

91 Ibid.

92 Ibid., 61.

93 Peter Conrad, The Medicalization of Society: On the Transformation of the Human

Condition into Treatable Disorders (Baltimore: The Johns Hopkins University Press, 2007), 4.
} 
Historians and social scientists are eminently qualified to consider the broader conditions of thought that contribute to the coherence and persuasiveness—-to the viability—of intellectual propositions like 'addiction.' They are also equipped to assess the consequences arising from the acceptance or rejection of such propositions. Taking Keeley's brain science seriously adds depth and urgency to our critical engagement with other theories of addiction without conclusively endorsing or rejecting any of them on their own medico-scientific terms. Though the evidence, not to mention its therapeutic application, may never match the claims that Alan Leshner and others have made for it, the NIDA model might eventually prove to be, as its backers claim, the long-sought-for physiological basis of addiction. But then again, it might not. Whatever the case proves to be, however, we can be pretty sure that it will not be the end point of addiction history or science. We can likewise be sure that history's role in understanding the challenges that confront addiction science has never been more important. This article has argued that context matters and this is precisely where History makes its strongest contribution to our understanding of addiction and its treatment. I have also argued that a re-evaluation of the life and work of Dr. Leslie E. Keeley is overdue. His ideas, his experience and his absence from the historical record are much more significant than we once thought, not least because they help us to think about 'addiction' today. 